\title{
Pengaruh Kemampuan Kerja dan Motivasi Kerja Terhadap Kinerja Karyawan PT. Semen Tonasa Kabupaten Pangkep
}

\author{
${ }^{1}$ Nurhaedah, ${ }^{2}$ Sukmawati Mardjuni, ${ }^{3}$ H.M. Yusuf Saleh \\ ${ }^{1}$ Program Pasca Sarjana Magister Manajemen \\ ${ }^{23}$ Program Pasca Sarjana Magister Manajemen \\ Universitas Bosowa,Makassar,Indonesia \\ Email:edhathalib70@yahoo.comemma_sumanti76@yahoo.com
}

\begin{abstract}
The purpose of this research is to know the magritude of the influence of the working ability and motivation work towards job satifaction and performance of employees. As well as to know the influence of job sansfaction of the employess en performance. The population in this study as many 232 employees, determining the number of sampel using sloving formula with a sample of 70 employees. The sampel using purpose sampling technique, the study analyzed by Structural Equation Modeling (SEM) with the help of software Smart PLS 2 basaed variance.From the result of the regression in obtai $n(1)$ the result and research shows that the positive effect of work ability and significantly to job satisfaction. (2) the result of the analysis of the influence of work on perpormance capabilities of employees shows there is significant and positive influence amongst (3) he working the analysisand the research shows there is a positive and significant influance between the motivation of working towards job satisfaction the thirtd hypothesis as proven the result of (4) the analysis on the research indicates there is a positive and significant influence between the working motivation afects so (9) this hypotesis proved the result on the analysis the research indicates there is a positive and significant influence between the job satisfaction on performance.
\end{abstract}

Keyword: Work Capability;Work Motivations; Job Satisfaction; Employees Performance

\begin{abstract}
Abstrak
Tujuan penelitian ini adalah untuk mengetahui besarnya pengaruh kemampuan kerja dan motivasi kerja terhadap kepuasan kerja dan kinerja karyawan, serta untuk mengetahui pengaruh kepuasan kerja terhadap kinerja karyawan. Populasi dalam penelitian ini adalah karyawan dan karyawati pada PT. Semen Tonasa di Kabupaten Pangkep Divisi Sumber Daya Manusia yasebanyak 232 karyawan, penentuan jumlah sampel menggunakan rumus slovin dengan jumlah 70 karyawan. Penentuan sampel menggunakan teknik purposive sampling, penelitian ini dianalisis melalui Structural Equation Modeling (SEM) dengan bantuan software Smart PLS 2 berbasis varians. Dari hasil analisis dan penelitian menunjukkan bahwa (1) kemampuan kerja berpengaruh positif dan signifikan terhadap kepuasan kerja. (2) Kemampuan kerja berpengaruh positif dan signifikan terhadap kinerja karyawan. (3) Motivasi kerja berpengaruh positif dan signifikan terhadap kepuasan kerja. (4) Motivasi kerja berpengaruh positif dan signifikan terhadap kinerja karyawan. (5) Kepuasan kerja berpengaruh positif dan signifikan terhadap kinerja karyawan pada PT. Semen Tonasa di Kabupaten Pangkep.
\end{abstract}

Kata Kunci: Kemampuan kerja, Motivasi kerja, Kepuasan kerja dan Kinerja karyawan

Link DOI : $\underline{\text { http://dx.doi.org/10.31314/pjia.7.1.11-21.2018 }}$

Copyright @ 2018, Publik : (Jurnal Ilmu Administrasi), ISSN: 2301-573X (Print), ISSN: 2581-2084 (Online) 


\section{PENDAHULUAN}

Era globalisasi mempunyai dampak dalam dunia usaha, globalisasi menimbulkan persaingan yang ketat di antara perusahaan-perusahaan untuk mendapatkan pangsa pasar yang dibidiknya. Dengan adanya globalisasi maka dunia usaha mau tidak mau didorong untuk mencapai suatu perusahaan yang efektif dan efisien. Keefektifan dan keefesienan dalam suatu perusahaan sangat diperlukan agar perusahaan dapat memiliki daya saing maupun keunggulan lebih dari para pesaing, sehingga perusahaan dapat bertahan dalam dunia persaingan yang ketat.

Karyawan merupakan aset perusahaan yang sangat berharga yang harus dikelola dengan baik oleh perusahaan agar dapat memberikan kontribusi yang optimal. Salah satu hal yang harus menjadi perhatian utama perusahaan adalah kepuasan kerja para karyawannya karena karyawan yang dalam bekerja tidak merasakan kenyamanan, kurang dihargai, tidak bisa mengembangkan segala potensi yang mereka miliki, maka secara otomatis karyawan tidak dapat fokus dan berkonsentrasi secara penuh terhadap pekerjaannya.

Kepuasan kerja karyawan merupakan "pekerjaan yang tidak hanya sekedar melakukan pekerjaan, tetapi terkait juga dengan aspek lain seperti melakukan interaksi dengan teman sekerja, atasan, mengikuti aturan-aturan dan lingkungan kerja tertentu yang seringkali tidak memadai atau kurang disukai”. Kepuasan kerja pada dasarnya merupakan hal yang bersifat individual. Setiap individual memiliki tingkat kepuasan kerja yang berbeda-beda sesuai dengan keinginan dan sistem nilai yang dianutnya.
Banyak faktor yang dapat mempengaruhi kepuasan dan berdampak terhadap peningkatan kinerja karyawan, namun dalam penelitian ini peneliti menfokuskan pada dua variabel yakni : kemampuan kerja dan motivasi kerja.

Motivasi bagi karyawan sangat penting untuk meningkatkan gairah dan semangat kerja, karyawanakan memiliki motivasi sesuai terhadap kemampuannya apabila organisasi dapat memenuhi kebutuhan karyawan. Usaha untuk memotivasi berarti memunculkan faktorfaktor (motif) yang mendorong orang berperilaku tertentu. Selanjutnya bahwa selain motivasi kerja hal yang terkait dalam penelitian ini adalah kinerja, dimana kinerja merupakan produk dari melakukan segala sesuatu yang berhubungan dengan suatu pekerjaan, jabatan, atau peranan dalam organisasi dengan penuh rasa tanggung jawab, dedikasi dan loyalit yang maksimum.kerja yang dimaksudkan dalam penelitian ini yaitu segala daya upaya yang dilakukan oleh pegawai dalam memberikan pelayanan administrasi terhadap Warga masyarakat, (Baderan,US,Ingo Yes pin, 2017).

Pentingnya masalah kemampuan dan motivasi kerja, maka penelitian ini difokuskan pada perusahaan PT. SemenTonasa, yakni salah satu perusahaan yang bergerak di bidang industri semen merek tonasa. Sebagai perusahaan yang berskala besar maka dituntut kinerja yang tinggi dari masing-masing karyawan untuk menjalankan aktivitas usahanya, oleh karena itu maka perusahaan perlu memperhatikan kepuasan kerja karyawan, karena dengan kepuasan yang dimiliki oleh setiap karyawan maka secara langsung akan mempengaruhi peningkatan kinerja karyawan. 
Berdasarkan pengamatan yang dilakukan, bahwa permasalahan yang sering terjadi pada perusahaan yakni kepuasan kerja karyawan mengalami penurunan sehingga mempengaruhi pencapaian kinerja karyawan, hal ini dapat dilihat dari kurangnya motivasi yang diberikan oleh perusahaan terkait aktivitas kerja, selain itu kurangnya kemampuan kerja karyawan, sehingga hal ini mempengaruhi turunnya kepuasan kerja dan kinerja karyawan, sedangkan kinerja karyawan sangat dituntut dalam menjalankan aktivitas usahanya, mengingat persaingan yang begitu ketat dengan perusahaan pesaing lainnya. Sehingga dengan adanya fenomena tersebut di atas maka perusahaan perlu memperhatikan mengenai kemampuan dan motivasi kerja karyawan sehingga dapat mempengaruhi kepuasan kerja karyawan dan akhirnya dapat meningkatkan kinerja karyawan pada PT. Semen Tonasa.

Banyak faktor yang dapat mempengaruhi kepuasan dan berdampak terhadap peningkatan kinerja karyawan, namun dalam penelitian ini peneliti menfokuskan pada dua variabel yakni : kemampuan kerja dan motivasi kerja. Kemampuan mempengaruhi kepuasan kerja karyawan, hal ini sesuai dengan teori yang dikemukakan oleh Robbins (2015 : 70)1 menyebutkan bahwa kemampuan langsung mempengaruhi tingkat kinerja dan kepuasan karyawan melalui kecocokan antara jabatan-kemampuan

Berdasarkan latar belakang tersebut, maka peneliti melakukan penelitian dengan judul sebagai berikut : “ Pengaruh Kemampuan Kerja dan Moitivasi Kerja Terhadap Kinerja Karyawan PT. Semen Tonasa di Kabupaten Pangkep “.

\section{METODE PENELITIAN}

Penelitian ini menjelaskan

kedudukan variabel-variabel yang diteliti Copyright (c) 2018, Publik : (Jurnal Ilmu Administrasi), ISSN: 2301-573X (Print), ISSN: 2581-2084 (Online) serta hubungan dan pengaruh antara satu variabel dengan variabel yang lain. Menurut Sugiyono (2004), Jenis penelitian yang menguji hubungan antara variabel penelitian disebut jenis penelitian explanatory research. Dengan demikian penelitian ini menjelaskan pengaruh variabel eksogenus variabel intervening Kepuasan kerja (Y1) terhadap kinerja karyawan (Y2). Data yang digunakan adalah data cross sectional yang akan dianalisis untuk menjelaskan fenomena variabel-variabel penelitian pada PT. Semen Tonasa. Berdasarkan analisis data, penelitian ini merupakan penelitian analisis, karena menganalisis data dari sampel dengan menggunakan statistik induktif untuk mengeneralisasi hasil penelitian pada populasi.

\section{Populasi Penelitian}

Menurut Sugiyono (2013) yang dimaksud dengan populasi adalah wilayah generelisasi yang terdiri atas obyek dan subyek yang mempunyai kualitas dan karakteristik tertentu yang ditetapkan oleh peneliti untuk dipelajari dan kemudian ditarik kesimpulannya. Populasi dalam penelitian ini adalah karyawan dan karyawati pada perusahaan PT. Semen Tonasa di Desa Biringere Kecamatan Bungoro Kabupaten Pangkep.

Sampel

Sampel adalah bagian dari jumlah dan karakteristik yang dimiliki oleh populasi. Sedangkan teknik penarikan sampel adalah suatu cara yang dipergunakan untuk menentukan sampel penelitian. Singarimbun mengungkapkan bahwa besarnya sampel tidak boleh kurang dari 5\% dari populasi yang ada. Untuk memenuhi kriteria tersebut maka pengukuran sampel dihitung dengan menggunakan rumus Slovin dalam Singarimbun (2006) sebagai berikut :

$$
\mathrm{n}=\frac{N}{1+N e^{2}}
$$


Keterangan :

$\mathrm{n}=$ Ukuran sampel

$\mathrm{N}=$ Ukuran Populasi

$\mathrm{e}=$ Presisi yang digunakan

Jumlah populasi dalam penelitian ini adalah sebanyak 232 orang. Presisi yang diambil sekitar 10 hingga 20\%. Namun dalam penelitian ini diambil presisi pengambian sampel $10 \%$ untuk menjaga reprenstatif dari sampel penelitian, sehingga diperoleh :

$$
\begin{gathered}
=\frac{232}{1+232(0.10)^{2}} \\
\mathrm{n}=70
\end{gathered}
$$

Berdasarkan hasil perhitungan tersebut maka dapat disimpulkan bahwa jumlah sampel dalam penelitian berjumlah 70 orang. Jumlah tersebut diambil dari karyawan yang berada pada Devisi Sumber daya manusia. pada PT. Semen Tonasa di Desa Biringere Kecamatan Bungoro Kabupaten Pangkep. Analisis data dalam penelitian ini dengan menggunakan metode Partial Least Square (PLS). PLS dapat digunakan pada setiap jenis skala data (nominal, ordinal, interval, dan rasio) serta syarat asumsi yang lebih fleksibel. PLS juga digunakan untuk mengukur hubungan setiap indikator dengan konstruknya. Selain itu, dalam PLS dapat dilakukan uji bootsrapping terhadap struktural model yang bersifat outer model dan inner model.

\section{HASIL DAN PEMBAHASAN}

Analisis kuantitatif dalam penelitian ini akan dilakukan pengujian pengaruh antara kemampuan kerja dan motivasi kerja terhadap kepuasan kerja dalam meningkatkan kinerja karyawan pada PT. Semen Tonasa Kabupaten Pangkep. Untuk menganalisis pengaruh kemampuan kerja dan motivasi kerja terhadap kepuasan kerja dalam meningkatkan kinerja karyawan digunakan software Smart Plus versi 2.0.
Pengujian Smart Plus dapat dikelompokkan dalam 2 bagian yakni outer model dan inner model, hal ini dapat diuraikan sebagai berikut :

\section{Outer Model}

Outer model merupakan model pengukuran untuk menilai validasi dan reliabel model melalui proses interaksi algoritma, parameter model pengukuran yang digunakan yakni convergen validity, discriminant validity, dan composite reliabilitydengan cronbach's alpha dan nilai Rsquare. Dalam hubungannya dengan uraian tersebut di atas akan dilakukan uji model (outer model) dalam penelitian ini yaitu sebagai berikut :

\section{a) Uji Validitas Konvergen (Covergent validity)}

Validitas konvergen berhubungan dengan prinsip bahwa pengukur dari suatu konstruk sehingga berkorelasi tinggi. Dimana suatu indikator yang memenuhi validitas konvergen jika mempunyai nilai loading yang di atas dari 0,50.

\section{b) Diskriminant Validity}

Diskriminant validity yang digunakan dalam penelitian berkaitan dengan pengukur-pengukur konstruk yang berbeda sehingga tidak berkorelasi tinggi.

\section{c) Uji Reliabilitas}

Uji reliabilitas diukur dengan composit reliability dan cronbach's alpha.

\section{Analisis Inner Model}

Inner model menggambarkan hubungan antara variabel laten berdasarkan pada substantive theory. Sebelum dilakukan analisis pengujian hipotesis maka terlebih dahulu akan disajikan gambar model PLS setelah dilakukan algoritma PLS dengan model PLS setelah bootstrapping. 
Tabel 1 Hasil R Square diolah dengan Smart PLS

\begin{tabular}{lc}
\hline & R Square \\
\hline Kepuasan kerja (Y1) & 0,656 \\
Kinerja karyawan (Y2) & 0,808 \\
\hline
\end{tabular}

Sumber : Diolah dengan Smart PLS

Tabel yakni nilai $\mathrm{R}$ Square, hal ini menunjukkan bahwa variabel kepuasan kerja yang dapat dijelaskan oleh kemampuan kerja dengan motivasi kerja sebesar $65,60 \%(0,656 \times 100)$, sedangkan sisanya yaitu sebesar $34,4 \%$ ( $1-0,656 \mathrm{x}$ $100 \%$ ) dapat ditentukan oleh faktor-faktor lain yang tidak diteliti. Sedangkan nilai Rsquare 0,808 yang menunjukkan bahwa

variabilitas kinerja karyawan sebesar $80,80 \%(0,808 \times 100)$ dapat ditekankan oleh adanya kemampuan kerja, motivasi kerja dengan kepuasan kerja, sedangkan sisanya sebesar 19,20\% ( 1 - 0,808) $\mathrm{x}$ $100 \%$ dapat dijelaskan oleh faktor-faktor lain yang tidak dimasukkan dalam penelitian ini, sehingga dalam pengujian ini dapat dikatakan bahwa model pengolahan data penelitian ini sudah baik. Hal ini dapat dilihat dari hasil penilaian goodness of fit yang dapat diukur dengan nilai Q2. Dalam menilai goodness of fit dapat dilakukan dengan uji Stone Geisser (Q2) dengan menggunakan rumus :

$$
\begin{aligned}
& \mathrm{Q} 2=1-(1-\mathrm{R} 121-\mathrm{R} 22) \\
& \mathrm{Q} 2=1-(1-0,656) \times(1-0,808) \\
& \mathrm{Q} 2=1-(0,344 \times 0,192) \\
& \mathrm{Q} 2=1-0,07 \\
& \mathrm{Q} 2=0,93
\end{aligned}
$$

Dari hasil perhitungan tersebut di atas diperoleh nilai $\mathrm{Q} 2=0,93$, artinya nilai observasi yang dihasilkan untuk model dan juga estimasi pendeteksian memiliki ketepatan sebesar 93\%. Berdasarkan hasil ini model struktural pada penelitian ini dapat dikatakan memiliki goodness of fit yang baik. Berdasarkan uraian tersebut di atas maka akan disajikan hasil pengujian pathdengan $t_{\text {hitung }}$ yang diolah dengan menggunakan Smart PLS yang dapat dilihat melalui tabel berikut ini :

Berdasarkan hasil koefisien jalur dari setiap variabel penelitian maka akan disajikan hasil pengujian hipotesis yang dapat diuraikan sebagai berikut :

a. Pengaruh kemampuan kerja terhadap kepuasan kerja (H1)

Berdasarkan hasil pengujian tersebut di atas diperoleh nilai koefisien dalam uji jalur sebesar 0,548, hal ini dapat diartikan bahwa setiap kenaikan kemampuan kerja yang dimiliki oleh karyawan maka akan dapat meningkatkan kepuasan kerja karyawan, sehingga dapat dikatakan bahwa secara empirik yang telah dilakukan diperoleh temuan bahwa makin tinggi kemampuan kerja yang dimiliki oleh karyawan dalam pelaksanaan kerja maka akan dapat meningkatkan kepuasan kerja karyawan. Kemudian dari hasil pengujian $\mathrm{t}$ diperoleh nilai $t_{\text {hitung }}$ sebesar 4,376, hal ini dapat disimpulkan bahwa dengan nilai $t_{\text {hitung }}$ sebesar 4,376 yang lebih besar dari 1,96 maka dapat dikatakan bahwa kemampuan kerja berpengaruh secara signifikan terhadap kepuasan kerja, sehingga dalam penelitian menemukan bahwa kemampuan kerja berpengaruh positif dan signifikan terhadap kepuasan kerja karyawan khususnya pada PT. Semen Tonasa di Kabupaten Pangkep.

b. Pengaruh kemampuan kerja terhadap kinerja karyawan (H2)

Berdasarkan hasil analisis mengenai pengaruh kemampuan kerja terhadap kinerja karyawan, dimana dari hasil pengolahan data dengan Smart PLS 2.0 diperoleh nilai koefisien sebesar 0,271. Hal ini dapat dikatakan bahwa setiap kenaikan kemampuan kerja yang dimiliki oleh karyawan maka akan dapat 
meningkatkan kinerja karyawan pada PT. Semen Tonasa Kabupaten Pangkep.

Kemudian dengan nilai $t_{\text {hitung }}$ sebesar 2,314, dengan nilai $t_{\text {hitung }} 2,314$ yang lebih besar dari 1,96, hal ini menunjukkan ada pengaruh signifikan antara kemampuan kerja dengan kinerja karyawan, sehingga dalam penelitian ini dapat dikatakan bahwa kemampuan kerja berpengaruh positif dan signifikan terhadap kinerja karyawan khususnya pada PT. Semen Tonasa (Persero) Kabupaten Pangkep.

c. Pengaruh motivasi kerja terhadap kepuasan kerja (H3)

Hasil uji jalur (Path) yang diolah dengan Smart PLS 2.0 diperoleh korelasi sebesar 0,303. Hal ini dapat diartikan bahwa setiap kenaikan motivasi kerja akan dapat meningkatkan kepuasan kerja karyawan, sehingga dalam penelitian ini dapat dikatakan bahwa makin tinggi motivasi kerja maka akan meningkatkan kepuasan kerja karyawan.

Kemudian dengan nilai thitung sebesar 2,402 yang lebih besar dari 1,96, sehingga dapat dikatakan bahwa motivasi kerja berpengaruh positif dan signifikan terhadap kepuasan kerja karyawan, yang artinya kenaikan motivasi kerja karyawan mempunyai pengaruh nyata terhadap peningkatan kinerja karyawan pada PT. Semen Tonasa di Kabupaten Pangkep.

d. Pengaruh motivasi kerja terhadap kinerja karyawan

Berdasarkan hasil pengujian yang diolah dengan menggunakan Smart PLS diperoleh nilai koefisien sebesar 0,272. Hasil ini dapat dikatakan ada pengaruh positif antara motivasi kerja dengan kinerja karyawan, dimana dapat disimpulkan bahwa makin tinggi motivasi kerja karyawan maka kinerja karyawan akan dapat ditingkatkan.
Kemudian dari hasil pengujian path diperoleh nilai t hitung $=3,167$ yang lebih besar dari 1,96. Hal ini dapat disimpulkan bahwa setiap kenaikan motivasi kerja karyawan akan dapat meningkatkan kinerja karyawan khususnya pada PT. Semen Tonasa di Kabupaten Pangkep.

Kemudian akan disajikan pengaruh langsung dan pengaruh tidak langsung dari setiap variabel melalui uraian yaitu :

1. Pengaruh langsung

a) Pengaruh kemampuan kerja terhadap kepuasan kerja

Berdasarkan hasil olahan data dengan menggunakan Smart PLS 2.0 maka besarnya pengaruh langsung setelah data diolah yaitu sebesar 0,548 dengan nilai $t$ hitung sebesar 4,376.

b) Pengaruh kemampuan kerja terhadap kinerja karyawan

Hasil uji jalur (path) dengan Smart PLS 2.0 maka besarnya pengaruh langsung sebesar 0,271 dengan nilai t hitung sebesar 2,314 .

c) Pengaruh motivasi kerja dengan kepuasan kerja

Hasil uji jalur (path) yang diolah dengan Smart PLS 2.0 maka besarnya pengaruh langsung antara motivasi kerja dengan kepuasan kerja sebesar 0,303 dengan nilai t hitung sebesar 2,402. Hal ini dapat dikatakan ada pengaruh yang positif dan signifikan antara motivasi kerja terhadap kepuasan kerja.

d) Pengaruh motivasi kerja dengan kinerja karyawan

Hasil uji jalur (path) yang diolah dengan Smart PLS 2.0 sebesar 0,272 dengan nilai t hitung $=3,167$.

2. Pengaruh tidak langsung

a) Pengaruh kemampuan kerja melalui kepuasan kerja terhadap kinerja karyawan. 
Tabel 2 Hasil Olahan data Pengaruh Langsung dan Pengaruh Tidak Langsung

\begin{tabular}{|c|c|c|c|c|}
\hline \multirow{2}{*}{$\begin{array}{l}\text { Variabel } \\
\text { Penelitian }\end{array}$} & \multicolumn{2}{|c|}{ Pengaruh langsung melalui } & \multirow{2}{*}{$\begin{array}{c}\text { Pengaruh } \\
\text { Tidak } \\
\text { langsung }\end{array}$} & \multirow{2}{*}{$\begin{array}{c}\text { Total } \\
\text { Pengarul }\end{array}$} \\
\hline & $\begin{array}{c}\text { Kepuasan } \\
\text { kerja }\end{array}$ & $\begin{array}{c}\text { Kinerja } \\
\text { karyawan }\end{array}$ & & \\
\hline $\begin{array}{l}\text { Kemampuan } \\
\text { kerja }\end{array}$ & 0,548 & 0,271 & 0,149 & 0,697 \\
\hline Motivasi kerja & 0,303 & 0,272 & 0,082 & 0,385 \\
\hline
\end{tabular}

Sumber : Hasil olahan data

Besarnya pengaruh tidak langsung kemampuan kerja melalui kepuasan kerja terhadap kinerja karyawan adalah sebesar $0,149(0,548 \times 0,272)$

b) Pengaruh motivasi kerja melalui kepuasan kerja terhadap kinerja karyawan

Besarnya pengaruh langsung motivasi kerja melalui kepuasan kerja terhadap kinerja karyawan sebesar 0,082 $(0,303 \mathrm{x}$ 0,272). Dalam hubungannya dengan uraian tersebut di atas maka besarnya pengaruh langsung dan pengaruh tidak langsung antara kemampuan kerja dan motivasi kerja melalui kepuasan kerja terhadap kinerja karyawan dapat disajikan melalui tabel 2.

Hasil penelitian menunjukkan bahwa kemapuan kerja berpengaruh positif dan signifikan terhadap kepuasan kerja dan kinerja karyawan pada PT. Semen Tonasa di Kabupaten Pangkep.

Sedangkan pengaruh motivasi kerja berpengaruh positif dan signifikan terhadap kepuasan kerja dan kinerja karyawan khususnya pada PT. Semen Tonasa di Kabupaten Pangkep. Untuk lebih jelasnya dapat disajikan pembahasan dari hasil penelitian ini yaitu sebagai berikut :

a) Pengaruh kemampuan kerja terhadap kepuasan kerja

Berdasarkan hasil analisis data penelitian melalui hasil pengujian model SEM diolah dengan Software PLS 2,0, dimana dari hasil analisis dan penelitian diperoleh temuan bahwa kemampuan kerja berpengaruh positif terhadap kepuasan kerja, hal ini dapat dikatakan bahwa secara empirik diperoleh temuan kemampuan kerja dapat meningkatkan kepuasan kerja.

Kemudian dari hasil uji signifikan yang menunjukkan bahwa kemampuan kerja berpengaruh signifikan terhadap kinerja karyawan, hal ini dapat diartikan bahwa kemampuan kerja berpengaruh nyata terhadap kinerja karyawan. Penelitian yang dilakukan oleh Dwi Astuti (2015) meneliti pengaruh kemampuan kerja, budaya organisasi terhadap kepuasan kerja karyawan di Center Point Mall Garden Malang. Hasil penelitian menunjukkan bahwa kemampuan kerja, kompensasi dan budaya kerja berpengaruh terhadap kepuasan kerja karyawan. Sedangkan penelitian yang dilakukan oleh Muh.Saleh (2011) meneliti pengaruh kemampuan kerja dan motivasi terhadap kepuasan kerja dan kinerja karyawan pada Bank Syariah di Kabupaten Jember.Dari hasil penelitian ini menunjukkan bahwa kemampuan kerja dan motivasi berpengaruh kepuasan kerja dan kinerja karyawan pada Bank Syariah di Kabupaten Jember, sehingga dari hasil data penelitian ini mendukung dari penelitian sebelumnya. b) Pengaruh kemampuan kerja terahdap kinerja karyawan

Berdasarkan hasil analisis SEM melalui Smart PLS diperoleh temuan bahwa setiap kenaikan kemampuan kerja dapat meningkatkan kinerja karyawan, sehingga secara empirik diperoleh temuan 
bahwa kemampuan pegawai dapat meningkatkan kinerja karyawan.

Kemudian dari hasil uji signifikan diperoleh hasil bahwa kemampuan kerja berpengaruh signifikan terhadap kinerja karyawan dimana makin tinggi kemampuan kerja maka kinerja karyawan akan semakin meningkat. Penelitian yang dilakukan oleh Muh.Saleh (2011) menemukan bahwa kemampuan kerja berpengaruh positif dan signifikan terhadap kinerja karyawan Bank Syariah.Sedangkan penelitian yang dilakukan oleh Syardiani (2014) meneliti pengaruh kemampuan kerja dan motivasi terhadap kinerja pegawai pada Dinas Perhubungan Komunikasi dan Informasi Kabupaten Kutai Timur.Hasil penelitian menunjukkan bahwa kemampuan kerja dan motivasi kerja berpengaruh signifikan terhadap kinerja pegawai, sehingga dari hasil penelitian ini mendukung dari penelitian sebelumnya.

c) Pengaruh Motivasi kerja terhadap Kepuasan Kerja

Berdasarkan hasil analisis dan penelitian yang telah dilakukan menunjukkan bahwa motivasi kerja berpengaruh positif terhadap kepuasan kerja dimana makin tinggi motivasi kerja maka kepuasan kerja karyawan akan semakin meningkat. Sedangkan dari hasil uji signifikan dalam penelitian inimaka dapat disimpulkan bahwa motivasi kerja berpengaruh signifikan terhadap kepuasan kerja, dimana motivasi kerja secara nyata dapat memberikan kepuasan kerja bagi karyawan.

Penelitian yang telah dilakkukan oleh Muh.Saleh (2011) yang menunjukkan bahwa motivasi kerja berpengaruh terhadap kinerja karyawan pada Bank Syariah Di Kabupaten Jember. Sedangkan Merliani (2006) yang meneliti mengenai pengaruh motivasi terhadap kepuasan kerja karyawan pada PT. Telekomunikasi Indonesia, Tbk. hasil penelitian menemukan bahwa motivasi kerja karyawan berpengaruh positif dan signifikan pada PT. Telekomunikasi Indonesia, sehingga dari hasil penelitian ini mendukung dari penelitian sebelumnya.

d) Pengaruh motivasi kerja terhadap Kinerja Karyawan

Berdasarkan hasil analisis dan penelitian yang telah dilakukan menunjukkan bahwa motivasi kerja berpengaruh positif terhadap kinerja karyawan, dimana dalam penelitian ini secara empirik dapat dikatakan bahwa motivasi kerja dapat meningkatkan kinerja karyawan khususnya pada PT. Semen Tonasa di Kabupaten Pangkep.Sedangkan dari hasil uji signifikan diperoleh temuan bahwa motivasi kerja berpengaruh terhadap kinerja karyawan.

\section{Implikasi Penelitian}

Penelitian ini memiliki implikasi dalam tiga aspek, yaitu implikasi pada aspek teoritis, implikasi pada aspek praktis dan implikasi pada aspek kebijakan. Implikasi penelitian pada aspek teoritis berhubungan dengan pengembangan keilmuan manajemen sumber daya manusia baik pada tataran teori maupun pada tataran empirikal yaitu :

1) Hasil analisis dan penelitian menunjukkan bahwa kemampuan kerja berpengaruh positif dan signifikan terhadap kepuasan kerja pada PT. Semen Tonasa di Kabupaten Pangkep, sehingga dalam penelitianini hipotesis (H1) terbukti.

2) Hasil analisis mengenai pengaruh kemampuan kerja terhadap kinerja karyawan yang menunjukkan ada pengaruh positif dan signifikan antara kemampuan kerja dengan kinerja karyawan pada PT. Semen Tonasa di Kabupaten Pangkep, sehingga hipotesis kedua terbukti. 
3) Hasil analisis dan penelitian menunjukkan ada pengaruh positif dan signifikan antara motivasi kerja terhadap kepuasankerja karyawan padaPT. Semen Tonasa di Kabupaten Pangkep, sehingga hipotesis ketiga terbukti.

4) Hasil analisis mengenai penelitian ini menunjukkan ada pengaruh positif dan signifikan antara motivasi kerja berpengaruh terhadap kinerja karyawan pada PT. Semen Tonasa di Kabupaten Pangkep, sehingga hipotesis terbukti.

5) Hasil analisis dan penelitian menunjukkan ada pengaruh positif dan signifikan antara kepuasan kerja terhadap kinerja karyawan pada PT. Semen Tonasa di Kabupaten Pangkep.

\section{Implikasi Praktis}

Penenlitian ini juga memberikan implikasi praktis bagi manajemen dalam pengembangan ilmu manajemen sumber daya manusia. Berikut ini beberapa implikasi praktis yang dapat ditemukan dalam penelitian ini :

1). Manajemen dapat memanfaatkan implikasi hasil penelitian ini dengan memanfaatkan Kemampuan kerja, Motivasi kerja dalam rangka meningkatkan kinerja karyawan melalui kepuasan kerja Pada PT. Semen Tonasa, apabila hal ini dapat diterapkan maka selanjutnya dapat meningkatkan kinerja perusahaan.

2). Variabel Kemampuan kerja dan motivasi kerja merupakan variabel yang paling besar pengaruhnya terhadap kinerja karyawan, sehingga apabila perusahaan senantiasa memperhatikan kualitas dan kuantitas Kemampuan kerja bagi karyawannya maka akan dapat memacu kinerja karyawan itu sendiri.

3) Kemampuan Kerja dan Motivasi Kerja merupakan wahana untuk meningkatkan kinerja karyawan, namun pengembangan kemampuan kerja tanpa memperhatikan kepuasan kerja, tentu akan mempengaruhi semangat kerja maupun loyalitas kerja karyawan. Pihak manajemen hendaknya lebih berupaya mempertahankan karyawan potensial dan berprestasi untuk pengembangan perusahaan kedepan. Perusahaan yang maju dan berkembang tentunya didukung oleh kualitas sumber daya manusia yang profesional di bidangnya dan mampu mengubah tantangan menjadi peluang strategis.

\section{Implikasi Kebijakan}

Penelitian ini menunjukkan pentingnya Kemampuan kerja dan Motivasi Kerja untuk meningkatkan kinerja karyawan. Hasil penelitian ini memberikan implikasi pada perusahaan khususnya pada Devisi Sumber daya manusia agar senantiasa

mendorong pengembangan kemampuan kerja melalui peningkatan keahlian dan keterampilan yang terstruktur.

Perusahaan hendaknya senantiasa melakukan penialaian kinerja secara rutin dan mengevaluasi hasilnya. Untuk melakukan peningkatan kemampaun kerja, perusahaan hendaknya mendorong kepada semua karyawannya untuk memacu kinerjanya dalam pengembangan kemampuan secara menyeluruh dan secara khusus kepada karyawan yang potensial.

Kepuasan kerja juga terbukti dapat meningkatkan kemampuan kerja dan kinerja karyawan sehingga diharapkan kepada pembuat kebijakan dalam hal ini perusahaan agar senantiasa memperhatikan mekanisme motivasi kerja kepada karyawan agar dapat mempertahankan kinerjanya.

\section{PENUTUP}

\section{Kesimpulan}

Berdasarkan hasil analisis dan pembahasan yang telah diuraikan, maka dapat disajikan beberapa kesimpulan dari hasil analisis yaitu sebagai berikut : 
1. Terdapat pengaruh Kemampuan Kerja terhadap Kepuasan kerja pada PT. Semen Tonasa di Kabupaten Pangkep, Semakin tinggi kemampuan kerja karyawan maka akan meningkatkan kinerja karyawan, kemampuan kerja tersebut dapat berupa kemampuan teknis, kemampuan konseptual dan kemampuan sosial.

2. Terdapat pengaruh Motivasi Kerja terhadap Kepuasan kerja pada PT. Semen Tonasa di Kabupaten Pangkep, Semakin tinggi Motivasi kerja karyawan dalam bekerja akan berdampak pada peningkatan Kinerja karyawan..

3. Terdapat pengaruh Kemampuan Kerja terhadap Kinerja Karyawan pada PT. Semen Tonasa di Kabupaten Pangkep, Kemampuan kerja karyawan berpengaruh secara langsung dalam peningkatan Kinerja karyawan, karyawan lebih bertanggung jawab dibidang pekerjaanya dan mampu menyusuaikan kualitas hasil pekerjaannya sesuai yang diharapkan perusahaa.

4. Terdapat pengaruh Movitasi kerja terhadap Knerja karyawan PT. Semen Tonasa yang dapat mempengaruhi meningkatkan kinerjanya, mempertahankan karyawan potensial dan berprestasi, meningkatkan loyalitas dan semangat kerja karyawan.

5. Terdapat pengaruh Kepuasan kerja terdapat Kinerja karyawan pada PT. Semen Tonasa, karyawan yang tingkat kepuasan kerjanya rendah akan mempengaruhi kinerjanya pada perusahaan, sebaliknya apabila karyawan mempunyai kepuasan yang lebih maka kinerja karyawan tersebut akan meningkat.

Saran
Adapun saran-saran yang dapat diberikan sehubungan dengan penelitian ini adalah sebagai berikut :

1. Sebaiknya perusahaan meningkatkan kemampuan kerja karyawan melalui pelaksanaan diklat sehingga dapat lebih meningkatkan kepuasan kerja yang berdampak terhadap kinerja karyawan.

2. Sebaiknya perusahaan lebih meningkatkan motivasi kerja karyawan yakni melalui pemberian insentif kepada karyawan yang berprestasi sehingga dapat memberikan kepuasan kerja dan kinerja karyawan.

3. Sebaiknya untuk lebih meningkatkan kepuasan kerja yang berdampak terhadap kinerja karyawan maka perlunya perusahaan lebih memperhatikan mengenai pemberian kompensasi, penghargaan bagi karyawan untuk berprestasi.

4. Disarankan agar memperhatikan aspek kompensasi guna dapat memberikan motivasi kerja yang berdampak terhadap peningkatan kinerja karyawan.

5. Disarankan untuk meningkatkan kinerja karyawan maka sebaiknya perusahaan dapat memberikan insentif-insentif kepada karyawan guna dapat memberikan kepuasan kerja sehingga kinerja karyawan di waktu yang akan datang dapat lebih meningkat.

\section{DAFTAR PUSTAKA}

Alwi, Syafaruddin. (2008). Manajemen Sumber Daya Manusia, edisi kedua,. cetakan pertama, Yogyakarta. BPFE-Yogyakarta

Arikunto, S. (2010). Prosedur Penelitian : Suatu pendekatan Praktik. Jakarta: Rineka Cipta

Abu Ahmadi \& Widodo Supriyono. (2004). Psikologi Belajar. Jakarta : Rineka Cipta

Badeni, (2013). Kepemimpinan dan Perilaku Organisasi, cetakan pertama, Bandung : Alfabeta 
Baderan,US, Ingo Yespin. (2017). Kinerja Pegawai dalam Pelayanan

Administrasi di Kantor Kecamatan Boliyohuto Kabupaten Gorontalo. Publik : (Jurnal Ilmu Administrasi). 6 (2), 127-134.

Darsono dan Tjatjuk Siswanto. (2011). Manajemen Sumber Daya Manusia, edisi pertama. Jakarta : Penerbit : Nusantara Consulting

Fahmi Irham. (2013). Manajemen Kepemimpinan Teori dan Aplikasi, Bandung : Penerbit : Alfabeta

Marwansyah. (2012). Manajemen Sumber Daya Manusia. Bandung: Alfabeta

Saleh, Muh (2011). Pengaruh Kemampuan, Motivasi Terhadap Kepuasan dan Kinerja Karyawan Pada Bank Syariah di Kabupaten Jember. Jurnal vol.1 November 2011

Robbins, Stephen dan Timothy A. Judge, (2015). Perilaku Organisasi Organizational Behavior. Jakarta : Salemba Empat

Sembiring Masana, (2012). Budaya Kinerja Organisasi, (Perspektif Organisasi Pemerintah). Bandung : Fokus Media

Siagian, P. Sondang. (2013). Manajemen Sumber Daya Manusia. Jakarta : Bumi Aksara,

Singarimbun, Masri dan Sofian Effendi. (2006). Metode Penelitian Survei. Jakarta: LP3ES

Sugiyono, (2013). Metode Penelitian Kuantitatif, Kualitatif dan $R \& D$. Bandung: CV.Alfabeta 